\title{
SLOVAKIA AND AUSTRIA \\ - A COMPARISON OF AGRICULTURE AND FOOD SECTORS
}

\author{
Ludmila Bartóková ${ }^{1}$
}

Received: November 16, 2018 / Revised: February 7, 2019/ Accepted: March 12, 2019

(C) Association of Economists and Managers of the Balkans, 2019

\begin{abstract}
Input-output tables with input-output data represent a relatively simple but useful tool to analyze the structure of the economy or undergoing structural changes. These tables enable to quantify direct and indirect linkages within each economy, as well as to study demand or supply relationships between particular sectors. The aim of this paper is to present and compare the main characteristics of 2 selected sectors for Slovakia and Austria. The focus is on the agriculture and food sector and their characteristics using the input output data and analysis. We compared basic input and output multipliers in order to verify the similarities in the position and the development of these sectors in selected countries. Other objectives were analysis of sectors' backward and forward linkages, "measuring" of their strengths, the identification of key industries and concentration of their impacts. With accordance to our previous research and general trends, we expected a certain decline of importance over the analyzed period of 2000-2014.
\end{abstract}

Keywords: Input-Output Analysis, Multipliers, Backward and Forward Linkages, Agriculture Sector, Food Sector, Demand, Supply, Impact, Slovakia, Austria

JEL Classification C67 $\cdot$ F62 $\cdot$ L66

This paper was presented at the Second International Scientific Conference on IT, Tourism, Economics, Management and Agriculture - ITEMA 2018 - November 8, 2018, Graz, Austria, www.itema-conference.com

L’udmila Bartóková

ludmila.bartokova@tuke.sk

$1 \quad$ Faculty of Economics, Technical University of Košice, Nemcovej 32, 04001 Košice, Slovakia 


\section{INTRODUCTION}

Input-output tables (IOT) and analysis are based on the model presented by Leontief. This type of analysis is not new but still represents a rather useful way for assessing structural changes. It helps in studying sectoral interdependencies, existing linkages between sectors or their strength (Leontief, 1953).

This paper focuses on the agriculture and food sectors, sectors that were getting more attention mainly due to their general decreasing trend over previous decades. The aim of the analysis is to compare and evaluate the position and the development of these sectors in Slovakia (SK) and Austria (AT) over the period 2000-2014. The analysis was aimed on the strength of the sectors' demand and supply linkages, the importance of their positions in national economies (from the point of view of key sectors). In accordance with general trends and the previous research, it can be expected that sectors would have experienced fairly stable, but decreasing, trend over this period. Due to the limited extent, this paper presents only selected results. More detailed results can be provided upon request.

\section{LITERATURE REVIEW}

The economic importance of agricultural and food sectors declined over last decades. This trend can be observed in many European countries. It is even more pronounced in countries that shifted from centrally planned economy to market systems such as Central European, Baltic or Balkan countries. This transition process impacted various area of economic life of the countries, agriculture and food sectors included. On the other hand, "old" members of European Union (EU) were not subjected to such significant structural changes. These changes can be viewed as a part of the process that was necessary to assure a higher similarity of economic structures of "old" and "new" members. The EU accession meant that national agricultural policies needed to be revisited to assure their compliance with EU policies but it enabled countries to draw yearly financial resources (European Commission, 2018; Lauri, 2012; Némethová \& Civáň, 2017).

When analyzing position or importance of any sector in economy, various basic indicators can be used: e.g. the sector's share on overall output, employment, value added (VA), imports or exports (Pokrivčák, 2003). IO analysis represents another approach for sector analysis. Thanks to it we can verify to what extent the positions and impacts of agriculture and food sector correspond to their shares on the economy. IO tables supply information about activities of all sectors within the whole production process in economy, from the points of view of producers of inputs and buyers of inputs (Dujava, Lábaj \& Workie, 2011). This knowledge can be very useful when evaluating overall macroeconomic impacts of the changing demand in various sectors (D'Hernoncourt, Cordier \& Hadley, 2011).

IOT models allow calculating various types of multipliers: output, input, import, employment, income or value added multipliers (Lábaj, 2017). They can be calculated either as simple or total multipliers, depending on whether the household consumption is a part of the model (Pissarenko, 2003). IO approach is also focused on the analyses of demand and supply (D, S) relationships between sectors, i.e. backward and forward linkages (BL and FL). The strength of these linkages points out to the most important sectors, either on the D or S side. Sectors that have strong both $\mathrm{BL}$ and FL are usually qualified as key sectors to the economy. What is more, IO analyses help to understand whether these impacts are evenly dispersed throughout the whole economy or they are rather concentrated on a smaller number of other industries. 
One of the advantages of $\mathrm{IO}$ analyses is that the values of multipliers remain stable even for longer periods of time thanks to relatively stable structures of economies. As a result, even older values can be used for e.g. the assessment of the current situation or for predicting future impacts of changing demand (McLennan, 1995).

\section{METHODOLOGY}

We suppose that each economy can be divided in $\mathrm{n}$ sectors and there are various relationships linking these sectors. The structure of the economy can be in general described as follows (Miller \& Blair, 2009):

$$
\begin{aligned}
& \mathrm{X}_{1}=\mathrm{Z}_{11}+\mathrm{Z}_{12}+\ldots+\mathrm{Z}_{1 \mathrm{j}}+\ldots+\mathrm{Z}_{1 \mathrm{n}}+\mathrm{Y}_{1} \\
& \mathrm{X}_{2}=\mathrm{Z}_{21}+\mathrm{Z}_{22}+\ldots+\mathrm{Z}_{2 \mathrm{j}}+\ldots+\mathrm{Z}_{2 \mathrm{n}}+\mathrm{Y}_{2} \\
& X_{i}=Z_{i 1}+Z_{i 2}+\ldots+Z_{i j}+\ldots+Z_{i n}+Y_{i} \\
& \ldots \\
& X_{n}=Z_{n 1}+Z_{n 2}+\ldots+Z_{n j}+\ldots+Z_{n n}+Y_{n}
\end{aligned}
$$

where $\mathrm{X}_{\mathrm{i}}$ stands for total sector output for sector $\mathrm{i}, \mathrm{Y}_{\mathrm{i}}$ the final demand for this sector's production and $\mathrm{Zij}$ the intersectoral flows in this economy. The production of each sector can serve as the intermediate consumption (inputs for other productions) or can be used directly in other sectors (final consumption) (Duvajová, 2014; Habrman, 2013). When the flows of inputs from i to $\mathrm{j}$ are divided by total outputs $\mathrm{X}_{\mathrm{i}}$, we obtain technical coefficients that reflect the cost structure of each industry (Lábaj, 2014). The set of equations (1) can be rewritten to $X=A X+Y$ (2) and transformed to $X=(I-A)^{-1}(3)$. The matrix $(I-A)^{-1}=L$ (Leontief inverse matrix) helps to understand what are the total direct and indirect effects of any increase in the final demand for production in each sector. It is the base for the IO analysis.

When sector i increases its production, it generates additional demands for inputs from supplying sectors ( $\mathrm{D}$ or $\mathrm{BL})$. The higher production in i means higher volumes of products, i.e. inputs for other sectors and can stimulate their productions (S or FL) (Miller \& Blair, 2009; Reis \& Rua, 2009; Timmer, 2012). Logically, these linkages can vary from one sector or country to other. Normalized values of IO multipliers can be used as means for measuring the strength of BL and FL and for determining the importance of sectors. They also enable to verify whether sectors have more than average impact on the economic activity in other sectors (key sectors) (Reis \& Rua, 2009; Trinh, Le Hoa \& Giang, 2009; Wixted, Yamano \& Webbe, 2006). The distribution of impacts on other industries can be studied with the help of variation coefficients (VK), a common measure of dispersion of effects on the whole economy. VK show for each industry whether its effects are evenly distributed (lower values of VK) or they are concentrated on small number of other industries (higher values of VK) (Reis \& Rua, 2009; Timmer, 2012).

Nowadays, productions in various countries are interlinked and production processes are fragmented. That is why it is important to take into consideration the volume of imports that are generated by domestic production (volume of the imported inputs due to the increased domestic demand) as well as the volume of exports transported abroad. 


\section{RESULTS}

With regards to the limited extent of the paper, only the evolution of Agriculture and Food production was analyzed (sectors noted A01 and C10-12 according to ISIC Rev.4) (United Nations, 2017). The choice of sectors is linked to the certain decline of their production even though they can still be considered as basic ones in each economy. We would like to verify the similarities in their evolution and to compare possible changes in their positions for 2000-2014. Data for analyses come from WIOD Database covering the period 2000-2014 (World Input Output Database, 2018).

As mentioned before, the importance or the position of any sector can be described by basic indicators, such as the sector's share on total output, employment, VA, exports or imports. When we compare the characteristics of SK and AT, out of the 56 sectors, there are only few sectors with average sector shares exceeding $5 \%$ of total values for the whole economy. It was confirmed for all of observed indicators, i.e. average production share on total country's production (SK-4 sectors, AT-3 sectors), average employment share on total employment (SK-6, AT-7), average export share on total exports (SK-5, AT-5), average import share on total imports (SK-6, AT-4) and average VA share on total VA (SK-5, AT-6). The most important producers were the sectors of motor vehicles manufacturing (SK) and construction (AT); the most important employers were the sectors of education (SK) and human health and social services (AT). As for the exporting and importing sectors, the highest average shares were observed in the manufacture of motor vehicles. The highest share of VA on total VA was created in construction (SK) and real estate (AT) sectors.

Table 1 shows selected average values for a01 and c1012. The average shares of a01 and c1012 were low, not exceeding 5\% for the analyzed period. As for the overall trend, countries experienced declines in both production and employment shares vis-à-vis the overall values. The most significant declines (about 50\%) appeared in SK c1012 (production) and a01 (employment).

Table 1: Shares of sector output on total economy's output, shares of sector employment on total economy's employment (Source: own calculations, WIOD)

\begin{tabular}{|l|c|c|c|c|c|c|c|c|c|c|}
\hline & \multicolumn{4}{|c|}{ Sector output on total output (\%) } & \multicolumn{5}{c|}{ Sector employment on total employment } \\
\hline Country & $\mathbf{2 0 0 0}$ & $\mathbf{2 0 0 8}$ & $\mathbf{2 0 1 0}$ & $\mathbf{2 0 1 4}$ & $\boldsymbol{\Delta} \%$ & $\mathbf{2 0 0 0}$ & $\mathbf{2 0 0 8}$ & $\mathbf{2 0 1 0}$ & $\mathbf{2 0 1 4}$ & $\boldsymbol{\Delta} \%$ \\
\hline SK a01 & 3.75 & 2.51 & 1.96 & 2.47 & -34.1 & 4.78 & 2.61 & 2.34 & 2.18 & -54.4 \\
\hline AT a01 & 3.00 & 2.03 & 2.29 & 2.25 & -25.0 & 3.31 & 1.82 & 2.20 & 2.01 & -39.3 \\
\hline SK c1012 & 4.49 & 2.62 & 2.26 & 2.22 & -50.7 & 3.51 & 2.54 & 2.42 & 2.14 & -39.0 \\
\hline AT c1012 & 5.58 & 4.12 & 4.18 & 4.20 & -24.7 & 4.13 & 3.25 & 2.36 & 2.89 & -30.0 \\
\hline
\end{tabular}

Table 2 compares the average values of sectors' exports and imports on total exports and imports. It can be seen that the values are lower for a01 exports with an increasing trend. The c1012 recorded a slight decrease in average shares for SK and an increase for AT. On the other hand, imports showed mainly decreasing trend, with the exception of AT c1012 (+12\% over 2000-2014).

However, when compared to the average shares of exports and imports of other sectors, a01 and c1012 shares are rather low. E.g. in case of motor vehicles manufacturing, exports accounted on average for about $22 \%$ of exports and $19.5 \%$ of imports in SK. It was also the biggest exporter and importer in AT (10\% for exports, $9 \%$ for imports). 
Table 2: Shares of sector exports and imports on total country's exports and imports (Source: own calculations, WIOD)

\begin{tabular}{|l|r|r|r|r|r|r|r|r|r|r|}
\hline & \multicolumn{4}{|c|}{ Sector export on total export (\%) } & \multicolumn{4}{c|}{ Sector import on total import (\%) } \\
\hline country & $\mathbf{2 0 0 0}$ & $\mathbf{2 0 0 8}$ & $\mathbf{2 0 1 0}$ & $\mathbf{2 0 1 4}$ & \multicolumn{1}{|c|}{$\boldsymbol{4} \boldsymbol{2 0 0 0}$} & $\mathbf{2 0 0 8}$ & $\mathbf{2 0 1 0}$ & $\mathbf{2 0 1 4}$ & \multicolumn{1}{c|}{$\boldsymbol{\Delta} \%$} \\
\hline SK a01 & 0.92 & 1.54 & 1.53 & 1.55 & +68.48 & 3.18 & 1.51 & 1.55 & 1.91 & -39.94 \\
\hline AT a01 & 0.67 & 0.71 & 0.78 & 0.77 & +14.92 & 1.29 & 1.10 & 1.12 & 1.10 & -14.73 \\
\hline SK c1012 & 1.49 & 1.63 & 1.51 & 1.03 & -30.87 & 3.59 & 2.11 & 1.96 & 1.90 & -47.08 \\
\hline AT c1012 & 3.64 & 4.66 & 5.43 & 5.74 & +57.69 & 3.32 & 3.35 & 3.34 & 3.71 & $+11,75$ \\
\hline
\end{tabular}

Table 3 shows average shares of VA on total VA. Here again, we can state that none of the 2 sectors exceeded 5\% average share and were mostly below 3\% share. What is more, shares of VA for a01 and C1012 decreased over the period. The highest decline appeared in SK c1012. As for the other sectors in SK and AT, the highest shares of VA were identically recorded in construction and real estate sectors.

Values for the crisis period in 3 tables show rather mixed crisis impacts. The average shares of production, employment, export, import and VA on the total values suggest in some cases a slight decline around 2000-2009 with a subsequent recovery after 2010 or a continuing decline in others.

Table 3: Shares of sector value added on total country's value added

(Source: own calculations, WIOD)

\begin{tabular}{|l|c|c|c|c|c|}
\hline & \multicolumn{5}{|c|}{ Sector value added on total value added (\%) } \\
\hline country & $\mathbf{2 0 0 0}$ & $\mathbf{2 0 0 8}$ & $\mathbf{2 0 1 0}$ & $\mathbf{2 0 1 4}$ & $\boldsymbol{\Delta} \%$ \\
\hline SK a01 & 3.58 & 3.20 & 2.07 & 3.31 & -7.54 \\
\hline AT a01 & 1.40 & 1.11 & 1.02 & 0.98 & -30.00 \\
\hline SK c1012 & 2.94 & 1.83 & 1.60 & 1.47 & -50.00 \\
\hline AT c1012 & 2.08 & 1.81 & 1.95 & 1.87 & -10.10 \\
\hline
\end{tabular}

The next step consisted of the analysis using IO tables. Firstly, the intermediate production coefficients were calculated: technical coefficients (tk, for output), allocation coefficients (ak, for input) and import coefficients (ik, for import). They were used to calculate simple output, input and import multipliers (som, sim, simp). Lastly, the strength of demand and supply linkages (BL, FL) was verified.

Table 4 shows the min and max values, averages and medians of 3 multipliers. The results tell that higher average D impacts (som) appear in c1012. Each D increase of $1 €$ in c1012 should generate $1.93 €(\mathrm{SK})$ or $1.94 €(\mathrm{AT})$ of additional productions in supplying sectors. The highest $\mathrm{S}$ impact (sim av, AT a01) means that $1 €$ of agricultural production could generate $2.12 €$ of new production when looking forward. As for import multipliers (simp), their values are usually lower than som and sim. Here the average values range from 0.18 (SK a01) to 0.32 (AT c1012) meaning that for $1 €$ increase in D, new imports of about 0.21 (SK) or 0.26 (AT) $€$ would be needed.

When compared, values of average and median can be used for a simple evaluation of the stability of multipliers. Closer values would mean a higher stability while more distant values would mean a higher fluctuation or presence of a trend. Table 4 shows that the values are mostly identical or very close to each other. Slightly higher differences can be observed in SK c1012 (som, sim). 
Table 4: Output, input and import multipliers (Source: own calculations, WIOD)

\begin{tabular}{|l|c|c|c|c|c|c|c|c|c|c|c|c|}
\hline Country & $\begin{array}{c}\text { Som } \\
\text { min }\end{array}$ & $\begin{array}{c}\text { Som } \\
\text { max }\end{array}$ & $\begin{array}{c}\text { Som } \\
\text { av }\end{array}$ & $\begin{array}{c}\text { Som } \\
\text { med }\end{array}$ & $\begin{array}{c}\text { Sim } \\
\text { min }\end{array}$ & $\begin{array}{c}\text { Sim } \\
\text { max }\end{array}$ & $\begin{array}{c}\text { Sim } \\
\text { av }\end{array}$ & $\begin{array}{c}\text { Sim } \\
\text { med }\end{array}$ & $\begin{array}{c}\text { Simp } \\
\text { min }\end{array}$ & $\begin{array}{c}\text { Simp } \\
\text { max }\end{array}$ & $\begin{array}{c}\text { Simp } \\
\text { av }\end{array}$ & $\begin{array}{c}\text { Simp } \\
\text { med }\end{array}$ \\
\hline SK a01 & 1.40 & 1.90 & 1.62 & 1.61 & 1.47 & 2.11 & 1.68 & 1.62 & 0.18 & 0.31 & 0.24 & 0.23 \\
\hline AT a01 & 1.67 & 1.82 & 1.71 & 1.71 & 2.06 & 2.19 & 2.12 & 2.11 & 0.13 & 0.26 & 0.18 & 0.18 \\
\hline SKc1012 & 1.79 & 2.19 & 1.93 & 1.87 & 1.11 & 1.69 & 1.24 & 1.19 & 0.25 & 0.39 & 0.32 & 0.31 \\
\hline ATc1012 & 1.91 & 1.99 & 1.94 & 1.94 & 1.47 & 1.53 & 1.49 & 1.49 & 0.18 & 0.33 & 0.24 & 0.22 \\
\hline
\end{tabular}

The next step was the analysis of som and $\operatorname{sim}(\mathrm{BL}, \mathrm{FL})$ normalised values. Table 5 shows the average values of $\mathrm{nBL}$ and $\mathrm{nFL}$ for observed sector (left part) and for the whole economy (right part). Values of nBL and nFL higher than 1 indicate either backward or forward orientation of the sector (strong D or S linkage). If both linkages exceed 1, this sector is a key sector to the economy. From data in Table 5, a01 can be on average considered as key in AT while c1012 is only backward oriented. More detailed analysis confirms that SK a01 could have been qualified as key over 2000-2005.

Table 5: nBL and nFL, VK (Source: own calculations, WIOD)

\begin{tabular}{|l|c|c|c|c|c|c|c|c|c|}
\hline Country & $\boldsymbol{n B L} \boldsymbol{a v}$ & $\begin{array}{c}\boldsymbol{n B L} \\
\boldsymbol{V K} \%\end{array}$ & $\boldsymbol{n F L} \boldsymbol{a v}$ & $\begin{array}{c}\boldsymbol{n} \boldsymbol{F L} \\
\boldsymbol{V K} \%\end{array}$ & $\begin{array}{c}\text { Total } \\
\text { econ }\end{array}$ & $\boldsymbol{V K} \%$ & $\begin{array}{c}\boldsymbol{m i n} \\
(\mathbf{s e c t o r})\end{array}$ & $\begin{array}{c}\boldsymbol{m a x} \\
(\text { sector })\end{array}$ & $\boldsymbol{a} \boldsymbol{v}$ \\
\hline SK a01 & 0.98 & 4.41 & 0.99 & 6.12 & $\boldsymbol{S K}$ & $\boldsymbol{n B L}$ & $\begin{array}{c}1.33 \\
(\mathrm{C} 23)\end{array}$ & $\begin{array}{c}23.07 \\
(\mathrm{R}-\mathrm{S})\end{array}$ & 4.86 \\
\hline AT a01 & 1.06 & 1.71 & 1.24 & 2.03 & & $\boldsymbol{n F L}$ & $\begin{array}{c}1.75 \\
(\mathrm{~N})\end{array}$ & $\begin{array}{c}28.65 \\
(\mathrm{G} 46)\end{array}$ & 10.14 \\
\hline SK c1012 & 1.17 & 2.46 & 0.73 & 8.51 & $\boldsymbol{A T}$ & $\boldsymbol{n B L}$ & $\begin{array}{c}0.80 \\
(\mathrm{G} 47)\end{array}$ & $\begin{array}{c}10.32 \\
(\mathrm{C} 19)\end{array}$ & 2.55 \\
\hline AT c1012 & 1.20 & 1.01 & 0.88 & 1.05 & & $\boldsymbol{n F L}$ & $\begin{array}{c}0.74 \\
(\mathrm{G} 47)\end{array}$ & $\begin{array}{c}17.04 \\
(\mathrm{~A} 03)\end{array}$ & 3.84 \\
\hline
\end{tabular}

Based on demand and supply relationships the extent of the sector's impact can be determined thanks to VK (more or less concentrated effects). Higher values indicate stronger concentration; lower values refer to lower concentration and evenly dispersed impacts across the economy.

When comparing all sectors in 2 countries, we can see some differences (Table 5, right side). Table shows sectors with the most and the least concentrated average impacts on both demand and supply side. From this point of view we cannot affirm that countries have similarly distributed concentrations of effects. As for the observed sectors, their values of VK are lower than the countries' average VK. The only exception is SK c1012 with VK for FL at the level of 8.51\%. In general, we can conclude that on average, impacts on the demand side are more evenly distributed than on the supply side (VK for $\mathrm{nBL}>\mathrm{VK}$ for $\mathrm{nFL}$ ).

\section{CONCLUSIONS}

In the paper, the main characteristics of a01 and c1012 in SK and AT were presented and compared. Analyses compared the shares of sectors on the total output, employment, exports, imports and VA. With the exception of AT c1012, neither a01 nor c1012, exceeded 5\% share in total values. While the shares of production, employment, imports and VA were decreasing, the export shares became more important. 
Basic IO coefficients and multipliers in 2000-2014 were studied. The descending trend was fairly visible for som and sim but we observed increases in simp confirming the growing importance of foreign products on domestic markets. The stability of sectors was verified by comparison of average and median values. Higher differences were present only in c1012 confirming a possible trend (downward in SK, upward in AT).

The analysis enabled the verification of key industries. We expected that in accordance with weakening importance and sectors shares, they would not present key sectors characteristics what was also confirmed by calculations. The AT a01 was the exception (strong BL and FL). Lastly the distribution of impacts was verified via VK. VK were lower than average countries' VK, meaning that a01 and c1012 have their impacts much more evenly distributed than are SK or AT averages. The impacts on the demand side could be considered as more evenly distributed than on the supply side.

\section{ACKNOWLEDGEMENTS}

The data and the knowledge presented in this paper were obtained as a result of the Research Project "Economic implications and perspectives of the participation of the Slovak Republic in the process of production activities fragmentation within Global Value Chains". (VEGA/1/0961/16).

\section{REFERENCES}

D’Hernoncourt, J., Cordier, M. \& Hadley, D. (2011). Input-output multipliers- specification sheet and supporting material. Spicosa Project Report. (2011). Retrieved from: http://www.coastal-saf.eu/output-step/pdf/Specification\%20sheet\%20I_O_final.pdf

Dujava, D., Lábaj, M. \& Workie, M. (2011). Štruktúra ekonomiky a ekonomický rast: Ako naplnit' teóriu číslami. Bratislava: Iris, 2011. 269p. ISBN 978-80-89256-66-2.

Duvajová, L. (2014). Využitie multiplikátorov na kvantifikáciu objemu domácej produkcie vyvolanej výdavkami návštevníkov v cestovnom ruchu. Trendy v podnikání. 5(1). 55-63. Retrieved from: https://www.dfek.zcu.cz/tvp/doc/akt/tvp-1-2015-clanek-6.pdf

European Commission (2018). Agriculture in the European Union. Statistical and Economic Information. Retrieved from: https://ec.europa.eu/agriculture/sites/agriculture/files/statistics/ agricultural/2012/pdf/full-report_en.pdf

Habrman, M. (2013). Vplyv exportu na pridanú hodnotu a zamestnanost' v slovenskej ekonomike. EÚ SAV Working Papers, 53. Retrieved from: http:/www.ekonom.sav.sk/uploads/ journals/239_wp_53_habrman.pdf>. ISSN 1337-5598.

Lábaj, M. (2017). Štruktúrna dekompozícia globálnych hodnotových ret’azcov : Slovenská ekonomika v medzinárodnom porovnaní. Politická ekonomie. 65(5), 562-582. doi: 10.18267/j. polek.1162

Lábaj, M. (2014). Štrukturálne aspekty ekonomického rozvoja - Slovenská ekonomika v globálnych súvislostiach. Bratislava: Ekonóm. ISBN 978-80-7144-223-3.

Lauri, M. 2012. General overview of Estonian economy. Agriculture and Forestry. Estonica. Retrieved from: http://www.estonica.org/en/Economy/General_overview_of_Estonian_economy/Agriculture_and_forestry/

Leontief, W. (1953) Domestic Production and Foreign Trade; The American Capital Position Re-Examined. Proceedings of the American Philosophical Society, 97(4). 332-349.

McLennan, W. (1995). Australian national accounts: Introduction to input-output multiplier. Retrieved from: http://www.abs.gov.au/AUSSTATS/abs@.nsf/DetailsPage/5246.01989-90?OpenDocument 
Miller, R. E. \& Blair, P. D. (2009). Input - Output analysis. Foundation and Extensions (2nd ed.). Cambridge, New York: Cambridge University Press. ISBN 978-0-521-739-02-3.

Néméthová, J. \& Civáň, M. (2017). Regional differences in agriculture in Slovakia after its accession to the European Union. Quaestiones Geographicae 36(2), 9-21. Retrieved from: https://doi.org/10.1515/quageo-2017-0011

Pissarenko, D. (2003). Basics of input-output analysis. Retrieved from: http://demetrix.sourceforge.net/resources/2003_02_20_ioAnalysis/ioAnalysis.pdf

Pokrivčák, J. (2003) Development of the Slovak agriculture and agricultural policies during the transition period. Agricultural Economics 49(11). 553-539. Retrieved from: https://doi. org/10.17221/5443-AGRICECON

Reis, H. \& Rua, A. (2009). An input-output analysis: Linkages vs leakages. International Economic Journal, 23(4), 527-544. doi: 0.1080/10168730903372323

Timmer, M. (2012). The world input-output database (WIOD): Contents, Sources and Methods. Retrieved from: http://www.wiod.org/publications/source_docs/WIOD_sources.pdf

Trinh, B., Le Hoa, P. \& Giang, B., C. (2009). Import multiplier in input-output analysis. Journal of science, economics and business. 25(5), 41-45.

UN. (2017) United Nations International Industrial Classification revision 4. Detailed structure and explanatory notes. Available at: https:/unstats.un.org/unsd/cr/registry/regcst.asp?$\mathrm{Cl}=27$

WIOD. (2018). World Input Output Database National Input Output Tables - Slovakia, Estonia, Latvia, Lithuania. 2000 - 2016. 2016 release. (2017). Retrieved from: http://www.wiod.org/ database/niots16.

Wixted, B., Yamano, N., Webb, C. (2006). Input-output analysis in an increasingly globalised world. Application of OECD's harmonized international tables. doi: 10.1787/18151965 